\title{
Recent Case Law on Custody and Second Marriage in Bangladesh: A Trend Towards Secularisation of the Legal System? ${ }^{1}$
}

\author{
By Shahdeen Malik
}

The first census of colonised Bengal, in 1872, 'discovered' that "Bengal proper, hitherto considered primarily the domain of the Hindus, was inhabited by an unexpectedly large number of Muslims." ${ }^{2}$ More importantly, in the eastern divisions ${ }^{3}$ of Bengal (Rajshahi, Dacca and Chittagong) Muslims constituted around $60 \%$ of the population. In the same year the second edition of W.W. Hunter's book The Indian Musulmans marked the beginning of a wide dissemination of his contentions that the Indian Muslims were markedly disadvantages by the British rule. He asserted that "[o]ne hundred and fifty years ago it was almost impossible for a well born Musulman in Bengal to become poor, at present it is almost impossible for him to continue to be rich." 4 He also claimed that the Muslims of India formed a 'homogeneous community'. 5 This 'discovery' of a muslim majority, along with the growing perception of exploitation by the British Raj and Hindu zamindars, and gradual consolidation of the notion of one Muslim nation in India (later fostered by M.A. Hinnah's "two nation theory" ${ }^{6}$ ) ultimately led to the creation of an Islamic country, Pakistan.

After 25 years of Pakistan and, more importantly, exactly a century after the 'discovery' of the Muslim majority, Bangladesh in 1972 became a secular state. History, it might have

1

Helpful comment of Dr. W.F. Menski and Taslima Mansoor on an earlier draft is acknowledged. Usual caveats apply.

Ahmed, R., The Bengal Muslims 1871-1906: A Quest for Identity, 2nd ed., New Delhi 1989, p. 1.

Burdwan and Calcutta Presidency were the two western divisions.

in Hunter, p. 155, quoted by Karim, A.K.N., The Dynamics of Bangladesh Society, New Delhi 1980, p. 38. But Nazmul Karim has shown that there were hardly any Muslims among the large zamindars of pre-British Bengal (ibid., at pp. 34-35, 46-47) and large Hindu zamindars were a creation of Murshid Quli Khan in the early 18th century rather than the East India Company in the early 19th century. See also Ahmed, R. (ed.), Religion, Nationalism and Politics in Bangladesh, New Delhi 1990 , pp. 4-5 for another critical evaluation of Hunter's analysis; and Islam, S., The Permanent Settlement in Bengal: A Study of its Operation 1790-1819, Dacca 1979, for zamindari structure of the period; and Ray, R., Change in Bengal Agrarian Society c1760-1850, New Delhi 1979.

Supra note 2, at p. 1 .

6 But see Jalal, A., The Sole Spokesman: Jinnah, the Muslim League and the Demand for Pakistan, Cambridge 1985, for a differend account of Jinnah's politics. 
been seen in 1972, has completed a full circle over a century - from Hindu Bengal to Muslim Bengal to Islamic Pakistan and finally to secular Bangladesh. But now, almost a quarter of a century later, it seems that the circle, as it were, was never really rounded up. There is a new arc to the circle now - an Islamic arc. This essay, metaphorically, is about this arc. It is that the act is still moving, but towards a different circle, a circle of secularism.

The essay is divided into three parts. The first part outlines the origin and problematic of secularism during the $1972-75$ period and its collapse in 1988. The second part argues that despite the constitutional 'Islamic' character of the state, the judiciary, in matters concerning Muslim family law, is applying bourgeois-liberal-egalitarian paradigm and not Islamic norms and principles. The third part suggests that his new trend towards secularization of the legal system is indicative of an emerging societal consensus concerning the role of religion in state and polity.

\section{Secularism}

Art. 8 of the 1972 Constitution was the mainspring of secularism. Secularism, the article stated, was one of the four fundamental principles of the state policy. ${ }^{7}$

Bangladesh in 1972, unlike the figures revealed by the 1872 census, was an overwhelmingly muslim majority country. The Muslim population hat increased from less than $60 \%$ in 1872 to $85 \%$ in 1972 . However, in 1972 Bangladesh was certainly not the only nor the first muslim-majority country to adopt a policy of secularism. Of the 25 major Muslimmajority countries, 9 do not have Islam as their of ficial religion and 6 of these - Gambia, Guinea, Niger, Senegal, Turkey and Yemen - are in fact secular states. ${ }^{8}$ Turkey was the first such country to adopt secularism.

Secularism, like many other 'general principles' of governance, is subject to a wide range of interpretation and understanding. Broadly, secularism is the establishment of a separation between religious matters and state activities. But a country can be secular even without this formal separation, as in the case of UK. The absence of a formal-legal separation between the church and the state in UK is not indicative of the societal perceptions

7

Huq, A.F., Constitution Making in Bangladesh, Pacific Affairs, vol. 46 (1973), p. 59; Ahmed, M., Bangladesh: Era of Sheik Mujibur Rahman, Wiesbaden 1984, ch. IV.

8

Maniruzzaman, T., Bangladesh Politics: Secular and Islamic Trens, in: Chakravarty, S.R. / Narain, V. (eds.), Bangladesh: History and Culture, Vol. 1, New Delhi 1986, pp. 42-77, at p. 46 lists these six countries plus Sudan which has subsequently adopted Islam as its of ficial religion. See also reprint of the same article in Ahmed, R. (ed.), Religion, Nationalism and Politics in Bangladesh, New Delhi 1990 , pp. 63-93, at p. 67. 
regarding the interconnection between matters religious and matters governmental. In other words, the state in UK is secular despite the absence of the formal separation between religion and state, and official activities are not normatively influenced by religious dictates or norms. In the USA, on the other hand, despite the longstanding constitutional separation between the church and the state, the political arena is often swayed by the puritan morality of a largely religious people. Similarly, religious perception in secular India continue to influence state activities.

Secularism, thus, hardly rests on a clearly delineated boundary between state and religion, or rigid models. More importantly, the establishment of a formal model of separation between religion and governmental activities, where such a model has been adopted, neet not follow a singular path in all the countries.

In Turkey, for example, secularism was established largely by Kamal Ataturk's uncompromising actions. For Kamal Ataturk secularism was invariably linked with his modernization goals. In this context Bernard Lewis' summation of Kamal Ataturk's swift and bold process of secularizing Ottoman Turkey is worth recalling:

"Ataturk proceeded by one deliberate step after another, beginning with the abolition of the Caliphate in 1924, of the religious order in 1925, of Sharia Courts in 1926, and of Islam as the state religion in 1926."

Secularism in Turkey was clearly imposed from the top in virtually one sweep ${ }^{10}$ and later sustained by continuous governmental actions. For example, Latin script in place of the Arabic was introduced and the Islamic calendar was also abolished. ${ }^{11}$ Ataturk's stringent imposition of secularism, without any scope for dissent, continued for almost a quarter of a century ie., till the abolition of the one party system in 1950 .

In India, however, the secularism of the 1950 Constitution was preceded by almost half a century of debate and deliberation. For India, unlike Turkey, secularism came after articulation and discussion. Whereas in Turkey secularism was not predated by a public disputation, in India Nehru's writings and speeches firmly placed the secular agenda into public debate already from the 1920s. For Nehru, religion was a "hinderance to the tendency to change and progress inherent in human society", and "the belief in supernatural agency

Lewis, B., The Emergence of Modern Turkey, London 1968, cited by Mitra, S., Desecularizing the State: Religion and Politics in India after Independence, Comparative Studies in Society and History, vol. 33, No. 4 (1991), p. 755, at p. 766. See also Esposito, J.L., Islam and Politics, 2nd ed., Syracuse 1987, pp. 95-99.

10

And this was done in the backdrop of a worldwide Khilafat Movement to preserve the Ottoman Empire.

11

Yalman, N., On Secularism and its critics: Notes on Turkey, India and Iran, Contributions to Indian Sociology, vol. 25 (1991), p. 233, at p. 245. 
which ordains everything has led to a certain irresponsibility on social plane, and emotion and sentimentality have taken the place of reasoned thought and inquiry." ${ }^{12}$ Nehru's shaping influence of the Congress party's policy of secularism was crucial, but the party had already indicated its inclination towards secularism as early as 1886 . By the late 1930s the ideology of secularism against the 'communalism' of the Muslim League had become "a mahor battle cry of the Congress" ${ }^{13}$, and after independence the policy of secularism in India was taken for granted.

It is not my suggestion that secularism in Bangladesh ought or must follow one of these two differential models, in one of which (Turkey) secularism was determinedly imposed from the top and sustained by the full power and sometimes force of the state apparatus, or in the other (India) where secularism was both preceded and proceeded by a sustained national debate and articulation in the political arena. ${ }^{14}$ Two considerations, however, suggest certain relevance of the experience of these two countries for Bangladesh. Unlike most other muslim-majority countries which are secular, Turkey's secularism is now sustained in a multi-party democratic structure and her modernization goal is not without resonance for Bangladesh. As for India, the fact of geographical proximity and her real or perceived influence (economic, political and hegemonic) over the polity in Bangladesh is not inconsequential.

Unlike Nehru's quintessential renaissance-rationale, or Turkey's state imposed secularism, the anti-communal stance of the Awami League in East Pakistan politics (1954-1970) ${ }^{15}$ and, more importantly, the experience of the liberation war of 1971 were the only influencing factors for embracing the policy of secularism in Bangladesh. In fact, secularism for Bangladesh emanated more from a direct and intensely cataclysmic national experience, rather than from a process of deliberate and rationalizing debate. Shah Alam has suggested this appraisal in vigorous terms:

"It was the bitter experience of communalism and the abuse of religion by autocratic rulers that has led to a national consensus as to the imperative need to ensure that in independent Bangladesh there should be an abolition of communalism in all its form, renunciation of abuse of religion for political purposes and the elimination of

Mitra, S., The Limits of Accommodation: Nehru, Religion and the State in India, South Asia Research, vol. 9 No. 2 (1989), p. 107, pp. 112, fn. 13, quoting Nehru, J., Discovery of India, Bombay 1961, p. 543 For a different view, ibid.

Bhuyian, A.W., Emergence of Bangladesh and role of Awami League, New Delhi 1982; Rizvi, H.A., Internal Strife and External Intervention, Lahore 1981, ch. 3. 
discrimination between person and person on the basis of religion. This consensus was reflected in the original contract, ie. the 1972 Constitution." 16

This 'bitter experience', however, showed only what sort of state Bangladesh should not $b^{17}$ - a religious state. But later the experience was not transposed into an articulated justification. In fact there were neither any attempts to rationalize secularism nor impose it forcefully. Consequently, it was in the narrower formulation of a negative and defensive policy of religious neutrality and not in the all-encompassingNehru-modernistic mode ${ }^{18}$ that secularism came to be understood in Bangladesh. ${ }^{19}$

This experience-derived ${ }^{20}$ brand of secularism, unsupported by even a minimal effort to supply sustained rationale, justification or articulation in the immediate post-independence period (1972-75), ${ }^{21}$ became an easy prey to the religious forces after the political changes of $1975 .^{22}$ In the absence of garnered support for secularism, each passing year inevitably increased the temporal distance from the shaping experience of 1971. Coupled with this, the growing influence of religion-based political forces in the world of popular perception, and the instrumentalist approach ${ }^{23}$ to religion of the post-1975 ruling groups fatally undermined the role of secularism.

The constitutional policy of secularism first came under fire after the overthrow of Sheik Mujibur Rahman's government in 1975. Soon afterwards the political forces which preferred a more religious orientation for the country accumulated enough pressure to

Shah Alam, The State-Religion Amendment to the Constitution of Bangladesh: A Critique, Law and Politics in Africa, Asia, and Latin America, vol. 24 (1991), p. 209, at pp. 214-215.

17

Dennis Wright, Islam and Bangladesh Polity, South Asia, vol. X, No. 2 (1987), p. 15, at p. 24.

Madan, T.N., Secularism in its Place, Journal of Asian Studies, vol. 46 No. 4 (1987), p. 749, highlights this tension between the narrow and broad notions of secularism in India.

19

On such an understanding of the issue, Maniruzzaman's critique of Sheik Mujib's secularism becomes somewhat superficial, in: Maniruzzaman, $T$., supra note 8.

Before the experience of 1971 liberation war, the Awami League's Draft Constitution Amendment Bill 1969 contained the name "Islamic Republic of Pakistan", in: Ahmed, M., Bangladesh: Constitutional Quest for Autonomy 1950-1971, Wiesbaden 1978, Appendix at p. 320. Shiv, L, BangladeshPak Polities, New Delhi 1985, at p. 87 comments in the Manif estofor the 1970 election: "The Awami League affirms that a clear guarantee shall be embodied in the Constitution to the effect that no law repugnant to the injunction of Islam as laid down in the Holy Quran and Sunnah shall be enacted or enforced in Pakistan."

For historic dimensions of secular politics, see Part III - Bengal Renaissance: The Secular Humanist Tradition, in: Kopf, D. / Joardar, S. (eds.), Reflection on the Bengal Renaissance, Rajshahi 1977; Kabir, M.G., Minority Politics in Bangladesh, New Delhi 1980.

On retrospect, it seems that Badruddin Omar's apprehensions expressed in The Weekly Holiday on 22 October 1972 proved correct in 1975. See also Banu, R.A., The Fall of the Sheikh Mujib Regime: An Analysis, Indian Political Science Review, vol. XV (1981), p. 1. 
bring about the incorporation of the words 'Bismillah-ar-Rahman-ar-Rahim (in the name of Allah, the Beneficent, the Merciful)' into the Preamble of the Constitution. The statutory instrument ${ }^{24}$ which added those words to the Preamble also amended Art. 8 to provide for "The principles of absolute trust and faith in the Almighty ..." and deleted secularism as one of the four principles of state policy. ${ }^{25}$ Furthermore, Art. 12 of the 1972 Constitution that envisaged the realisation of secularism ${ }^{26}$ through elimination of "(a) communalism in all its forms; (b) the grantin by the State of political status in favour of any religion; (c) the abuse of religion for political purposes; (d) any discrimination against, or persecution of, persons practising a particular religion" had to be deleted to remove the obvious contradiction with the now declared "trust in the Almighty Allah". ${ }^{27}$

This whittling away of secularism, ${ }^{28}$ begun in 1977 , culminated in the adoption of the Eight Amendment in 1988 by actually declaring Islam as the state religion. ${ }^{29}$ This Amendment added a new Art. 2A to the Constitution to declare Islam as "the state religion of the Republic". ${ }^{30}$ This provision for a state religion finally and conclusively displaced secularism as one of the 'fundamental principles of state policy'. However, this constitutional islamization has not yet been translated into any overtly Islamic Law. Unlike Pakistan, where islamization from the top ${ }^{31}$ was quickly followed by enactment of selective

Proclamation Order No. 1 of 1977 of the Marial Law regime.

The Proclamation Order No. 1 of 1977 also added a novel elaboration of socialism, which, as one of the fundamental principles, now meant "economic and social justice". Art. 10 of the 1972 Constitution which had stated that "a socialist economic system shall be established with a view to ensuring the attainment of a just and egalitarian society free from exploitation of man by man" was now substituted by a new Art. 10: "steps shall be taken to ensure participation of women in all spheres of national life."

Zillur Rahman Khan has written: "In order to ensure that nationalism would bring about secularism, Mujib had added a specific provision to the 1972 Constitution (ie., Art. 12) ... Mujib saw Bengali Nationalism as a composite of Bengali culture, language, folklore, mores and the general Bengali environment from which Bengalis could receive inspiration and be motivated to strive for the uplift of their society.". In: Khan, Z.R., Islam and Bengali Nationalism, Asian Survey, vol. 25 no. 8 (1985), p. 834 , at p. 846.

Arts. 25 and 38 were also amended.

Ahmed, M., Bangladesh: Constitutional Quest for Autonomy 1950-71, Wiesbaden 1978, details the pre-independence evolution of constitutional ideals and concepts.

For a background to these development, see Huq, A.F., Constitutional Development (1972-1982), in: Chakravarty, S.R. / Narain, V. (eds.), Bangladesh: Domestic Politics, Vol. 2, New Delhi 1986, pp. 49-83; also Huq, A.F., Contemporary Politics and the Radical Left in Bangladesh, Journal of the Institute of Bangladesh Studies, Vol. III (1978), for the role and tactics of both Islamic right and radical left during 1977-1978.

30 Bangladesh Gazette Extraordinary, 9th June, 1988; also Constitution (Eight Amendment) Act 1988, 40 DLR (1988) Statute 93.

For a recent overview, see Kennedy, C.H., Islamization and Legal Reform in Pakistan (1979-89), Pacific Affairs, vol. 63 (1990), p. 62. 
Islamic laws, ${ }^{32}$ Bangladesh has not only not initiated a process of incorporating rules of Islamic laws into its legal system, ${ }^{33}$ but the judiciary is actually moving away from the religious norms. The following part II offers an analysis of this judicial activism.

\section{Legal Reasoning}

From a scrutiny of the published case reports, we find that the logic, reasoning and underlying assumptions of recent judicial pronouncements clearly indicate a trend towards secularisation of the legal system of Bangladesh, despite the ostensible Islamization of the Constitution.

Marriage and social relations that are derivative of marriage, ie., divorce, custody of children, legitimacy and inheritance, are governed by Muslim law. Wakf, pre-emption and gift are the other major non-marital or non-personal arena of social relations still regulated by Muslim law.

Our examination of the recently published cases on marriage related issues indicates that their underlying legal postulates are permeated primarily by notions of formal equality of sexes, perceptions of the welfare state, and concerns for natural justice. In other words, even in matters that are governed by traditional Muslim law, increasingly, the evolving

Whether islamization of laws through legislative or executive enactments is itself Islamic is an issue which, though occasionally raised, has not been convincingly resolved. For example, in B.Z. Kai Kaus $v$ President of Pakistan 1980 PLD SC 169, the petitioner contended that there was no need for human legislation to impose the Shariah as the Quran and Sunnah already contain all the legal norms.

Formulating Shariah through legislative enactments by itself implies inadequacies of these norms as contained in the Quran and the Sunnah. Ayatollah Ruhollah Khomeini, like many others, had argued (in his Islam and Revolution, Berkeley 1981) that there was no need for drawing up laws in an Islamic state as everything necessary already exists in the major sources of the Shariah. Needless to say, Khomeini opted for a different interpretation after coming to power.

Legislative enactments on such normatively well understood crimes as zina have produced vastly different punishments in Libya, Pakistan and Sudan to highlight the problems involved in Islamization through legislation.

These issues are detailed in Mayer, A.E., The Shariah: A Methodology or a Body of Substantive Rules?", in: Heer, N. (ed.), Islamic Law and Jurisprudence, London-Seattle 1990, pp. 172-198. See also Khadduri, M., The Islamic Concept of Justice, Baltimore 1984.

The secular constitution, however, did not embrace any directive, similar to Art 44 of the Indian Constitution, for a uniform civil code to override personal laws. On this issue, see Pearl, D., Bangladesh: Islamic Laws in a Secular State, South Asian Review, vol. 8 no. 1 (1974), p. 33. Taslima Mansoor drew my attention to this article. 
legal culture is that of an egalitarian rationality and liberal equality rather than that of religious orthodoxy. ${ }^{34}$

In the legislative arena a number of laws were enacted in the 80 s to ameliorate the subjugated conditions of women. The recent cases, along with these laws, signify the shift towards a legal culture which is more sympathetic as well as symptomatic of formal equality between the sexes. There is also a growing reluctance on the part of the judiciary to adhere to the notions of the pre-determined roles ${ }^{35}$ designated to different segments of the society by the religious orthodoxy. ${ }^{36}$ It is not argued that a pronounced trend towards equality of sexes is, per se, a move away from Islamic principles. Our suggestion is that the reasoning of the case law reveals a growing incorporation of those arguments which can more easily be traced to liberal enlightenment origins, and are premised more on nonreligious considerations, rather than the principles and doctrines of a strict Islamic legal culture.

To validate such an assessment of the recent development of the legal regime of personal laws in Bangladesh, we shall primarily focus on cases that have offered new understanding an dinterpretation of the traditional Muslim law issues. Custody and second marriage are two such arenas of Muslim law which have recently been subjected to judicial scrutiny

It is not imputed that the concepts of equality, welfare state and natural justice are incompatible with Islamic legal culture. Rather, the process if Ijtehad which would be essential to derive such principles from the existing Islamic norms and traditions is not being attempted with sufficient vigour.

Haeri, S., Divorce in Contemporary Iran: Male Prerogative in Self-Will", in: Mallat, C. / Connors, J. (eds.), Islamic Family Law, London 1990, pp. 55-69, has argued that the legal determinism ("nikah is a contract for ownership, tamlik of the use of the vagina" quoting Iranian scholars - at p. 57), biological determinism ("Women psychologically and physically want to put themselves under man's protection" - at p. 59), and divine determinism (divinely ordained right of man to divorce his wife without cause - at p. 62) determine mutual rights and obligations of the spouses in Shi'i Islam.

36

As a typical example of traditional popular perception of the duties and responsibilities of women in Bengal, the following dictates from the pages of a late nineteenth century fundamentalist text are sufficiently illustrative: "The Lord has given man higher status: women must follow the orders of their husbands. A woman has no rest so long as she is alive. She has to serve her husband and thus worship Allah ... There are some cantankerous women who quarrel if their husbands take more wives. The holy book says such women are scoundrels." In: Ahmed, R., The Bengal Muslims, 1871-1906: A Quest for Identity, 2nd ed., New Delhi 1988, p. 87 and fn. 76 therein. See also Metcalfs analysis of what can easily pass as one of the most influential 'adab' books for Indian Muslim women - Ashraf Ali Thanawi's Bihisti Zewar (1906) in "Women in Islamic Reform and Islamic Women: Moulana Thanawi's Jewelry of Paradise", in: Metcalf, B.D. (ed.), Moral Conduct and Authority: The Place of Adab in South Asian Islam, London 1984, pp. 184-196.

For a spirited rejection of the pervasive ideal of such meek, submissive and veiled Muslim women, see Kabbani, R., The Gender Jihad, in The Guardian, 22.1.92, p. 37, particularly her comment: "The heavy veiling that we see across the Muslim world and among Muslim communities elsewhere is certainly not islamic; it is a dead relic from Byzantium, which the Arabs took on when they conquered my native Damascus soon after Muhammad's death, and saw fit to ape the conservative customs of the Christian elite they there displaced." Also Kabbani, R., Europe's Myth of Orient, London 1986, for Western images of alluring Eastern women. 
and, hence, constitute the core of our analysis. In addition, the decisions on The Dowry Prohibition Act 1980 that have opined on those aspects of marital relationship which are relevant for our purposes are also taken into account for a better perspective of trends and attitudes towards Muslim law.

Two caveats are, however, in order. First, Muslim law of inheritance, wakf, and gift continues to retain its orthodox Hanafi imprints and these are applied in accordance with the rules, principles and interpretations evolved in the British Indian courts since, at least, the mid-nineteenth century. ${ }^{37}$ Secondly, one may easily posit, given the political dominance of the military during the fifteen year period from 1975 to 1990, a cynical expediency argument ${ }^{38}$ for these moves towards incorporating Islam as the state religion. Therefore, constitutional Islamization was perhaps neither meant to reflect the political sentiments of the majority of the populace of the country nor indicated a radical realignment of political forces.

\section{Custody}

The Muslim law in the Indian subcontinent has generally entrusted the mother with the custody of her daughter until puberty, and of her son until the attainment of 7 years of age. The mother can maintain the custody even if she is divorced, but loses her right on her (re)marriage. ${ }^{39}$ A clear restatement of this rule is found in the case of Akhtar Jahan Tanyia Alias Bad \& Anor. $v$ The State. ${ }^{40}$ Explaining another relevant rule of Muslim law, the Court stated that the mother's guardianship is "lost by operation of law as soon as she marries another person who is not related to the minor girl within the prohibited degree." 41

But the mother's forfeiture of her right of custody on attainment of a predetermined age (for sons) or physical condition (for daughters) is not treated with the circumspection of an inviolable norm. This and other related rules, it has been accepted, is subject to judicial discretion. For example, a forceful assertion of the scope for such discretion in interpreta-

Anderson, M., Islamic Law and the Colonial Encounter in British India, in: Mallet, C. / Connors, J. (eds.), supra note 35 at pp. 205-225.

38 For example, "On the other hand, it may be a merely cosmetic decision", in: Kabeer, N., The Quest for National Identity: Women, Islam and the State in Bangladesh, IDS Discussion Paper 268, 1989, p. 24.

39 Mahmood, T., Muslim Law of India, 2nd ed., Allahabad 1987; Mulla, Principles of Mohammadan Law, 17th ed., Bombay 1972.

401986 BLD 281.

41 Ibid., at p. 283. 
tion of a related rule was indicated in Mlvi. Rehanuddin $v$ Azizun Nahar. ${ }^{42}$ In this case the High Court, confirming the District Judges's decision, stated "although the appellant was the natural guardian (being the paternal grandfather) under the Muslim law, the mother in the fact and circumstances of the case was entitled to be appointed as the guardian." ${ }^{43}$ The "fact and circumstances" in which the mother is awarded the custody is revealing: "... the mother of the minors was not treated properly at the house of her inlaws even during the life time of her late husband." ${ }^{44}$ The fact that the mother was illtreated by her in-laws, arguably, is not related to the situation or condition of the children, unless one assumes that the anticipated treatment of the mother as daughter-in-law is, by itself, a clear indication of the treatment to be meted out to the children as grandchildren. The Court, however, does not spell out any such assumption, nor does it indicate any inherent connection between the in-laws' attitudes towards the mother and her children. There is neither any clear finding by the Court nor any inference to the purport that the illtreatment of the mother was or is likely to be repeated towards the children.

In the absence of any argument linking the two obviously separate issues of treatment of daughter-in-law and grandchildren, the Court's reliance on the ill-treatment of the mother as the ground for awarding her the custody of the child can be appreciated only if we look at it, first, as an overt attempt to reach a particular result, and secondly, as a bid to broaden the grounds on which a decision in favour of a mother may be justified and rationalized.

The Appellate Division case which has dealt with this issue of custody in exhaustive detail is that of A. Baker Siddique v S.M.A. Baker. ${ }^{45}$ This case relied on a host of custodycases of the pre-1971 Pakistan Court to, first, expound the relevant rules as interpreted and accepted by the Pakistani Courts, and secondly, reject the orthodox Muslim law position which favours the custody rights of fathers. The primary issues in Siddique $v$ Baker was the custody of a boy aged 8 years. The father claimed custody of his son from his divorced wife mainly on the ground that, according to the Muslim law, the custody of the son, who is more than 7 years old, devolved on the father. The Court did not accept this rule, and basing its conclusion on a number of precedents, reiterated that "the Court, in all these cases, seems reluctant to give automatic effect to the rule of Hizanat ${ }^{46}$ enunciated by Islamic jurists."

42

43

44

45

46
33 DLR (1981) HCD 139.

Ibid., at p. 140 .

Id.

38 DLR (1986) AD 106.

According to T. Mahmood: "Muslim Law splits guardianship of person into two facts. One of this consists of the physical custody and day to day upbringing of the minor - and this is called hizanat ... 
A more sweeping argument for deviation from the orthodox Muslim law rule regarding hizanat $^{48}$ was earlier advanced in Zohra Begum v Latif Ahmed Munwar ${ }^{49}$ and the resoning of this decision was quoted in length in Siddique $v$ Baker with approval. The justification for deviating from the rule of hizanat, the Court pointed out, was that "there is no Quranic or Traditional Text on the point ... (and) ... the rule propounded in different Text Books on the subject of Hizanat is not uniform." ${ }^{50}$

For the Court in Siddique, the relevant factors for overruling the rule of hizanat were, first, that there is a lack of uniformity in text books, and secondly, there are no explicit and relevant Quranic provisions. This assumption that an absence of direct Quranic provisions entitles one to discard norms of Islamic Law can ultimately undermine the authenticity of a whole range of rules and norms. Apparently such ramification were not central to the Court's concerns in this particular case. Rather, this assumption ostensibly emboldened the Court to advance and fortify the "primacy of welfare" as the determining criterion. Such an understanding of hizanat had already been accepted in Pakistan, and the Bangladesh Supreme Court used and reaffirmed this position in Siddique v Baker.

The law awards the hizanat of minor, to begin with primarily to its mother: it is taken away from her after the child attains a particular age." In: supra, note 39, p. 163.

47

An important hizanat-related issue is whether the mother can remove the child to a place where the father can not exercise supervision and control over the child. The earlier interpretations, as Mulla indicates, proscribes the mother from removing the child to a place which is distant from the father, even during the period when she is entitled to custody: "and if she does so, she losses her right to custody of the child", in: Mulla, supra note 38, p. 333. For such an understanding of Muslim Law Mulla (in the 17th ed., published in 1972) cites the cases of Ali Akbar v Kaniz Maryam 1956 PLD Lahore 484, and Muhammad Bashir v Ghulam Fatima 1953 PLD Lahore 73, both decided by Justice B.Z. Kaikaus. But such an interpretation of the custody rights of the mother was explicitly overnuled by the Pakistan Supreme Court in Rahimullah Chowdhury v Helali Begum 20 DLR (1968) SC 1. The Supreme Court ruled: "However, if it was intended to lay down in Ali Akbar v Mst Kaniz Begum that if such a right be forfeited then the minor must be retumed into the custody of the father ipso facto as was done in the case of Mst Mahmoda Khatun $v$ Sayed Zainul Hossain Rezvi without determining whether it will be for the welfare of the minor or not to do so, we find it difficult to subcribe to this view." Ibid., at p. 16. In this Chowdhury case the estranged mother had moved her two sons from the residence of their father. The determining question was "whether under Muslim Law a mother looses the hizanait of her children of tender age of she removes them from the ordinary residence of the father" (p. 3). The Court opted, as indicated, for a negative determination of the question. However, "a mother may ... be deprived of the custody of the children of tender age only if the paramount consideration their welfare so demand" (p. 17). The welfare argument, it is evident, was asserted as the determining one rather than the rule of the orthodox hizanat as wrongly suggested by Mulla.

49

50

Siddique v. Baker, supra note 47, at p. 114, quoting from Zohra Begum v Latif Ahmed Munwar 1965 PLD Lahore 695. 
The significance of the criterion of "welfare of the minor" in deciding the issue of custody is also recognized in s. 17 of the Guardian and Wards Act. It seems that although the concept of welfare does not occupy a central position in the scheme of the personal law, yet it has become the governing principle in a range of decisions. Consequently, the issue of custody is more often decided with reference to welfare of the child rather than to dictates of Muslim law.

The determining importance of the welfare criterion has been reiterated by te Supreme Court in Siddique. The Court cited relevant precedents, it seems, not only to confirm that in these cases the "welfare of the minor child" was of paramount importance, ${ }^{51}$ and therefore it should be so in similar cases, but also to restate the import of the same in more forceful and unambiguous language:

"Indeed, the principle of Islamic Law (in the instant case, the rule of hizanat or guardianship of minor child as stated in the Hanafi School) has to be regarded, but deviation therefrom would seem permissible as the paramount consideration should be the child's welfare." 52

It is, thus, evident that these recent cases have increasingly relied on the criterion of welfare of the child to the impairment of the traditional personal law, and we take this as one important indication of the secularisation of laws in Bangladesh. It needs mentioning that the validity of the Hanafi rule that the custody right of the mother is lost when she (re)marries someone not within the prohibited degree of relationship has not been tested in any court. But given the tenor of the recent decisions and the constant reiteration of the paramountcy of the welfare of minors, an appropriate factual situation where the mother's remarriage could be shown to be helpful or otherwise beneficial for the welfare of the minor and, conversely, a transfer of custody to the father or his representatives would be shown to be harmful, could provide the courts with an opportunity to reinterpret this (remarriage) aspect of the custody law to reflect the new trend.

\section{Second Marriage}

The right of a Muslim male to have up to four wives is commonly recognized. All schools agree that a Muslim man does not, as summed up by David Pearl:

"require a permission to enable him to contract a second or subsequent marriage up to a maximum of four. The requirement in Sura IV verse 3 (to treat the two or more

"The concept of the welfare of the minor child, whether below or above the age limits, seems to have been of paramount importance", supra note 44, at p. 113.

Ibid., at p. 117, emphasis added. 
wives equally) is construed again by all Schools as a requirement to be decided upon by the husband himself. It is his responsibility and he has no need to submit himself to examination by any person or institution in advance of the final decision to contract a second or subsequent marriage. Again, the moral injunction - for such it is - to treat four wives equally relates to nafaga (support and maintenance) and not to equal impossible task. The rights of several wives to equal and impartial treatment arise after the marriage." 53

This orthodox position, needless to say, has undergone tremendous change in most of the Muslim countries in recent years. Saudi Arabia is among the very few countries in the Middle East where recent legislation has not imposed any restrictions on the right of a Muslim man to two or more wives. But Turkey and Tunisia have completely abolished the right to contract a second marriage. In between these two opposite poles lies a host of other countries such as Jordan, Syria, Iraq and Morocco who have restricted this capacity. $^{54}$

The Muslim Family Laws Ordinance 1961 (hereafter MFLO) of Pakistan ${ }^{55}$ can, on a conservative interpretation, be easily classified as a legislative attempt to erect a few procedural barriers for contracting a second or subsequent marriage. The procedure for contracting a second and subsequent marriage is contained in s. 6 of the Ordinance. The primary requirements for the husband for contracting a second marriage consists inobtaining a written permission from the Arbitration Council. Such permiddion is granted on the basis of an application by the husband stating his grounds for the proposed second (of subsequent) marriage. The application must also state "whether the consent of the existing wife or wives has been obtained". ${ }^{56}$ The Arbitration Council, comprising the Chairman of the local body and a representative each of the husband and wife or wives, may grant such permission "if satisfied that the proposed marriage is necessary and just". 57 Any marriage contracted without such permission is not void, but subjects the husband to "simple imprisonment which may extend to one year, or with fine which may extend to ten thousand taka, or with both". 58

Pearl, D., A Textbook on Muslim Personal Law, 2nd. ed., London 1987, pp. 77-78. But such interpretation, though generally accepted, is not without its dissentors. For a different interpretation of the relevant Quranic verses (iv. 3 and iv. 129) see Esposito, J.L., Women in Muslim Family Law, Syracuse 1985, pp. 92-93, and Kabbani, R., The Gender Jihad, supra note 36.

Ibid., at p. 69. For details on Jordan see Welchman, L., The Development of Islamic family law in the legal system of Jordan, International and Comparative Law Quarterly, vol. 37 (1988), p. 868.

57 subs. 3 of s. 6 .

58 cl. b., subs. 5, s. 6 . 
Farooque Miah $v$ Tahera Begum ${ }^{59}$ is the first reported case of the 80 s which deliberated on the role of the Arbitration Council under s. 6 of the MFLO. In this case the husband who had married without the requisite permission, argued that "since there was neither Union Council nor 'chairman' as contemplated under section 2(b)(d) of the Ordinance when the second marriage was contracted ie., on 17.8.75 there was really no way to form 'Arbitration Council' as contemplated under section 2(a)". ${ }^{60}$ In the absence of the Chairman and Arbitration Council "there was no competent authority from whom the accused was required to take permission for contracting another marriage and as such he could not be convicted for an offence under section 6(5) of the Ordinance". ${ }^{61}$ The Court concluded that the relevant laws for formation and dissolution of local councils did not specifically provide for nomination or election of a Chairman with the appropriate authority and power to perform the necessary function of the Arbitration Council, and thereby agreed with the position of the husband.

Soon after this judgement, the MFLO (Amendment) Ordinance $1982^{62}$ was quickly promulgated to correct this procedural lacuna. The amending Ordinance, in s. 3, laid down that "Chairman means the Chairman of the Union Parishad or Poaurashava". As such, any future application for permission for contracting a second or subsequent marriage could be addressed to such Chairman who would form the Arbitration Council. ${ }^{63}$

However, an opposite conclusion was drawn in the next published case. ${ }^{64}$ In this case, based on a heretofore unknown Notification of the Government, the Court decided that the Government had, in fact, appointed certain persons to perform the tasks of Chairman for the purposes of the MFLO in 1972, and the husband (in a factual circumstances similar to Tahera Begum) could and ought to have applied to such person (Chairman) for the requisite written permission to contract a second marriage.

It was the P.O. Order of 1972 which dissolved the then existing local councils that led to the confusion and opposite judgements in Tahera Begum and Ayesha Sultana. Art. 6 of the Order provided that:

59

60

1981 BLD 165.

61

Ibid., at p. 166.

Ibid., at p. 169.

62

63 In Tahera Begum v Farukh Miah 35 DLR (1983) AD 170, the Appellate Division upheld the High Court Division's decision that during 1975, ie., at the time of the second marriage there was no person or authority who was legislatively empowered, for the purposes of the MFLO, to constitute an Arbitra64 tion Council. 
"Notwithstanding anything contained in the Muslim Family Laws Ordinance 1961 (Ord. VIII of 1961) and the Conciliation Court Ordinance 1961 (Ord. XLIV of 1961) the functions of the Chairman or any member of a local Council under any of the Ordinances shall be performed by such person or persons as the Government may appoint in this behalf."

It seems that in the litigations between Tahera Begum and Farookh Miah in both the High Court and the Appellate Divisions, it was not brought to the notice of the Courts that in accordance with the above P.O. Order 72 of 1972 after the dissolution of the local Councils, the Government had actually appointed and empowered certain persons to perform the tasks of Chairman for the purposes of the MFLO. Consequently, in both the Tahera Begum cases the Courts mistakenly inferred that the Government did not act in accordance with the P.O. Order 72 since

"in order to invest a Chairman of the Union Parishad with function under the Muslim Family Laws Ordinance, express conferment of power was a prerequisite ... It can be legitimately inferred that the Legislature noticed the gap in Law after these pronouncements by the High Court Division." 66

But in Ayesha, the enterprising counsel for the appellant Ayesha located the relevant Notification of the Government:

"No. S-1/4R-1/72/532 - 18th November, 1972 - In exercise of the power conferred by Article 6 of the Bangladesh Local Councils and Municipal Committee (Dissolution and Administration) Order, 1972, the Government is pleased to appoint the Administrators of Union Panchayet, Sahr Committees and Poaurashavas to perform all the functions as provided under the Muslim Family Laws Ordinance 1961 and the Rules made thereunder within their respective areas. ${ }^{67}$

Thus, contrary to the inferences of the $\mathrm{HCD}$ and $\mathrm{AD}$ in the litigations between Tahera Begum and Farooque Miah that no one was empowered to act as the Chairman for matters connected with the MFLO, the Government by this Notification had authorized particular persons with the necessary powers to act in the capacity of the Chairman. The Court in Ayesha, based on this Notification, appropriately found that the Administrator of Dhaka Poaurashava was appointed and empowered to perform the function of forming an Arbitration Council.

Quoted in Farooque Miah v Tahera Begum, supra note 59, at p. 167. The P.O. Order was also relied upon in Tahera Begum v Farukh Miah, at p. 172. Emphasis added.

The two cases referred to here are Farookh Miah v Tahera Begum and an unreported judgement in Criminal Revision No. 507 of 1978 delivered by Justice A.S. Faizul Islam Chowdhury on 17 April 1980

38 DLR (1986) HCD 140. Emphasis added. 
This above detail of the procedural nature in appointment and empowerment of a Chairman to form an Arbitration Council is offered with a view to emphasize that the substantive right to a second or subesequent marriage may easily be subsumed under procedural technicalities. Procedural impediments were the primary justification in Farooque Miah $v$ Tahera Begum ${ }^{68}$ for the HCD and in Tahera Begum v Farukh Miah ${ }^{69}$ for the AD to refuse to penalize the husband for his second-marriage without the requisite written permission. The opposite inference of the Court in Ayesha was also premised on another technical-procedural Notification. In reaching their conclusion on procedural grounds, the Courts in all these cases avoided the substantive issue of the parameters of a husband's right to contract a second marriage. In fact, depending upon whether the issue of second marriage is framed purely in narrow procedural terms or posited as a matter of substantive rights, as was done in the later case of Abul Basher $v$ Nurun $\mathrm{Nabi}^{70}$, the larger issue can be subjected to judicial scrutiny. The High Court Divion in Abul Basher referred the case back to the trial judge for determining if the husband had obtained the requisite written permission from the Arbitration Council before contracting the second marriage. But going beyond this purely procedural aspect of the MFLO, the Court also offered some comments on the larger issue of polygamy, noting that "it seems that the legislative intent of section 6 of the Muslim Family Law Ordinance, 1961 is to restrict the practice of polygamy and to permit it only in cases where it appears reasonable to the Arbitration Council." 71

This comment touches on one of the most important aspects of s. 6 of the MFLO, whether the Ordinance purported only to streamline the right to contract more than one marriage during the subsistence of previous marriage(s) by ensuring that a certain formal procedure is followed, or the right was deliberately curtailed and restricted by imposing limitations through requirements of written permission based on negotiations and consent which would be granted only on a few pre-determined grounds. A scrutiny of the grounds on which a permission to contract a second or subsequent marriages are usually granted may indicate the impact of the restricting provisions. Unfortunately, there are no published materials based on empirical research to indicate whether or not the Arbitration Councils are utilising their authority to grant permission for second marriages in a restrictive manner.

\footnotetext{
68

1981 BLD 165.

69

35 DLR (1983) AD 170.

39 DLR (1987) HCD 333.

71

Ibid , at p. 335. Emphasis added.
} 
The Court in Abul Bashar neither offered any enumeration of the grounds which it would consider as reasonable for permitting a second marriage nor did it indicate its readiness to scrutinize the reasonableness of grounds if any were placed before it.

However, one indication of the grounds which are deemed sufficient or reasonable for granting a permission for contrating a second or subsequent marriage is contained in Rule 14 of the MFLO Rules. This Rule provides that for determining whether a proposed marriage is just and necessary, the Arbitration Council shall "have regard to such circumstances as the following amongst others: sterility, physical infirmity, physical unfitness for conjugal relation, wilful avoidance of a decree for restitution of conjugal rights, or insanity on the part of the existing wife". The enumeration of grounds in this rule is to exhaustive and therefore it does not preclude granting of the requisite permission on other grounds. But the tenor of the Rule clearly restricts the right to a second marriage to grounds of physical and mental infirmity only.

This rule was referred to in Makbul Ali \& Others v Munwara Begum ${ }^{72}$, where it was iterated that the MFLO "did not prohibit polygamy altogether but allowed it under certain conditions". ${ }^{73}$ More importantly, the Court re-enumerated the grounds for permission of the Rule, stating clearly that:

"in deciding whether it is proper and just to allow the application the Council shall have regard to such circumstances such as sterility, physical infirmity, physical unfitness for conjugal relation, wilful avoidance of a decree for restitution of conjugal rights, physical unfitness for any conjugal rights, or insanity on the part of an existing wife ..."

One reading of this aspect of the Court's pronouncement can surely be that it considered a second marraige permissible if it is "proper and just" and it can be so only on the grounds contained int he above mentioned Rule. On such a reading of the Court's intention, a second marriage is no longer a matter of right, but of permission and discretion. Thus, if the right to contract a second marriage is conditional upon permissions granted in strictly defined situations of physical or mental infirmity, the case law in Bangladesh can clearly be seen to have gone a long way in restricting the prerogatives of man in his marital relations. The substantive right to contract a second marriage is not denied by the court, but by subjecting the exercise of this right to the requirement of strictly defined notions of "proper and just", the court is evidently interjecting concepts of public policy and equity in an arena which is unusually considered the bastion of muslim male's prerogative.

39 DLR (1987) 181.

73

74

Ibid., at p. 183

Id. Emphasis added. 
From this case it can, thus, be argued that the conditions under which the permission for a second marriage is granted may not be substantially satisfied by merely following the formality of applying for and obtaining the written permission. A restrictive interpretation of the Rule 14 grounds can easily restrict the right to a second marriage to a very few situations of physical and mental infirmity, therefore making second marriage permissible only of proper and just in each and every given situation. ${ }^{75}$

\section{Other Issues}

Unlike India, the issue of maintenance of divorced Muslim wives beyond the Iddat period has not been adjudicated by any Court in recent years. But Justice S.M. Hussain has made a most direct and forceful plea in favour of substantive equality of the sexes which could of interest in a maintenance litigation. In the relevant judgement ${ }^{76}$ the issue of restitution of conjugal rights, claimed by the husband, was moot, as Justice Hussain had decreed that the marriage was already dissolved. Nevertheless, the dicta on restitution of conjugal rights do indicate an ingrained liberal attitude towards the issue of equality of sexes:

"A reference to Article 28(2) of the Constitution of Bangladesh guaranteeing equal rights of women and men in all spheres of the state and public life would clearly indicate that any unilateral plea of a husband for forcible restitution of conjugal rights as against a wife unwilling to live with her husband is violative of the accepted State and Public Principle and Policy."77

This powerful and unambiguous enunciation is another demonstration of the shift in judicial attitude. It clearly indicates the readiness of the Court to uplift the position of women to the plateau of actual equality vis-à-vis their relationship with husbands, even if such a change is detrimental to the traditional rights of husbands to claim restitution of conjugal rights against unwilling wives.

The Dowry Prohibition Act 1980 has been enacted to prohibit demands of dowry by husbands and to ameliorate certain disadvantageous conditions of women. In Rezaul

For a lively debate on this issue see the following articles in the Keral Law Times (KLT): Kkhan, M.M., Islamic Polygamy: A Blessing in Disguise, (1989) KLT (1) J 47-59; Menski, W.F., Comparative Legal Training in Action: A Reluctant Defence of Polygamy, (1990) KLT (2) J 50-69; Haq, F., Polygamy in Islam: Misrepresented and Ill-Judged, (1990) KLT (2) J 14-17; and Menski, W.F., Crocodile tears and Muslim Polygamy in India, (1991) KLT (1) J 20-24.

Nelly Zaman v Giasuddin Khan 34 DLR (1982) HCD 221.

77

Ibid., at p. 225. 
Karim v Mosammat Taslima Begum ${ }^{78}$, one of the two published cases on this Act, ${ }^{79}$ the Court in explaining the meaning of "demand for dowry" concluded that

"demanding money or other valuable security from the wife or her relations by the husband after she is married for giving her the status of a wife, namely maintaining her as a wife, protecting her as a wife and giving her a shelter would amount to demanding money in consideration for the marriage." 80

Such an understanding of the role of the Act, the concept of marriage, and the expansion of the meaning of "in consideration for marriage", again, clearly fosters the position of married women and is in harmony with the trend of secularizing case law.

One recent judgement, however, has squarely applied an orthodox rule of Hanafi Muslim law regarding past maintenance of a wife. In Rustom Ali $v$ Jamila Khatun ${ }^{81}$ the High Court Divison set aside the decree of lower Court granting past maintenance to the wife and son who was compelled to live apart from the man. In ruling that the wife is not entitled to past maintenance, the Court relied on Mulla's statement of relevant rule in his Principles of Mohammadan Law and a few very old precedents. ${ }^{82}$

More than 15 years ago Tahir Mahmood had argued that "Mulla is not an Act or a Code; in any case it is not 'Muslim law' ... The words, phrases and clauses in Mulla need not be construed with the aid of those principles of interpretation which are generally used in the construction of statute law", ${ }^{83}$ and pointed out a number of discrepancies in that book. ${ }^{84}$ It seems that by relying on Mulla's textbook the Court in Rustom Ali glossed over the rule that in the Shafi school similar past maintenance is allowed, ${ }^{85}$ more importantly:

"The hanafi jurists however have clearly laid down that in cases where the application of the Hanafi Law causes hardship, it is permissible to apply the provision of the Maliki, Shafei or Hanbali Law." 86

40 DLR (1988) HCD 360.

79 Earlier, the other published cases Mihir Lal Podder v Zhunu Rani Shah 37 DLR (1985) HCD 227, had reached an opposite conclusion on the meaning of demand for dowry. 43 DLR (1991) HCD 301.

For example, A. Futteh Moulvi v Zabunnessa Khatun 3 Indian Decisions (Cal ) (1881).

Mahmood, T., Muslim Law, Annual Survey of Indian Law, vo. X (1975) p. 364, pp. 375-376.

"Poor Mulla had never read even the most elementary of the original treaties on Islamic Law; nor did he ever claim to have done so. He only honestly codified that law as understood and interpreted by the British-Indian judges with their prejudiced brains and sinister design", in: Mahmood, T., Personal Law in Crisis, New Delhi 1986.

E.V. Kunhimarian v Ooramveettil Mammu AIR (1985) Jer 239, p. 240.

86

Annual Survey of Indian Law, Vol. XX (1985), p. 307. 
But it can be suggested that the above judgement in Rustom Ali does not reflect the general trend. For example, another recent case which has, in an obiter dictum, touched upon the shift in attitude in male-female relationship is that of Hasne Ara Begum v Alhaj Md Rezaul Karim. ${ }^{87}$ In this case the wife left her husband's residence on grounds of cruelty, and claimed maintenance for herself and her children for the period when she was staying with her parents. The trial court (Family Court) allowed her claim for maintenance, but the first Appeal Court disagreed and sent the case back for a re-trial. On appeal, the High Court Division rebuked the court below as it stated that "the Court of Appeal below, it appears, was guided by the archaic concept of absolute dominion of the husband over the wife and children" and by using expression such "... even under the Muslim law several rights have been recognised to the wife", 88 the Court clearly indicated its appraisal of Muslim law in less than sacrosanct terms and the consequent readiness to deviate from such law. This becomes less a matter of conjecture when we find the Court stating that "... in the well-to-do-family of the parties compelling the wife to do domestic work is also physical and mental torture" ${ }^{89}$ - to iterate its readiness to take social reality into account to understand the meaning of torture in marital relationship. Such an expansive use of the concept of torture to negate the husband's claim for restitution of conjugal rights and ordering him to pay maintenance is another indication of the gradual secularization of the understanding of the terms of marital relationship by the Courts in recent years.

Arguably none of these cases has attempted as far reaching a restructuring of Muslim personal law as the Shah Banu judgement in India. ${ }^{90}$ Neither have they introduced any explicit right which was not granted by Muslim law nor have they drastically curtailed any of the privileges of the Muslim male. Nevertheless, incorporation of certain concepts, logic and assumptions of a secular nature are clearly discernable and as such a shift away from the orthodox precepts can not be denied. ${ }^{91}$ A few of the orthodox rules have certainly been tempered with, but some other rules on issues such as legality and validity

87

88

89

90

Mohd. Ahmed Khan $v$ Shah Bano Begum AIR 1985 SC 945. On post Shah Bano Muslim Women (Protection on Rights on Divorce Act 1986), see Mahmood, T., Muslim Law, in: Annual Survey of Indian Law, Vol. XXIV (1989) at pp. 228-232; also idem, Islamic Law in the Indian Court - 1988, Islamic and Comparative Law Quarterly, vol. 9 (1989), p. 57; and idem, Islamic Family Law - the Latest Development in India, in: Mallat, C. / Connors, J. (eds.), Islamic Family Law, London 1990, pp. 295-320; and Malik, S., Saga of Divorced Women: One again Shah Bano, Maintenance and the Scope for Marriage Contracts, 42 DLR (1990) J 34-42.

91

A similar process of application of principles and assumptions of secular laws in matters governed by traditional Hindu law has been suggested in Menski, W.F. / Rahman, T., Hindus and the Law in Bangladesh, South Asia Research, vol. 8 (1988), p. 111. 
of adoption, right of maintenance of divorced wife and unequal division of inheritance between sons and daughters remain undisturbed. But surely a growing sensitivity regarding the subjugated positions of women in the legal framework is being recognized and courts do seem to be taking steps to fashion new parameters of personal law. The main impetus behind this trend is the growing acceptance of secular and rationalistic concepts, concerns, and notions of equality on this one hand, and diminishing sway of orthodox precepts on the other hand.

\section{Islam in Bangladesh Polity}

We have indicated, at the beginning of this essay, the contentions between secular and religious trends in Bangladesh politics. This friction is not without long standing historical roots and in many ways this divergence is being reflected in judicial pronouncements and legislative acts as already submitted. Going beyond the present tussle between these trends, it is not without relevance to note that Islam in Bangladesh, as elsewhere, is not devoid of local influences. It is now recognized that this local influence here is more pronounced than in many other parts of the world. ${ }^{92}$ The seminal work on this regard is, of course, that of Asim Roy. ${ }^{93}$ His two main arguments are, firstly, that the prominent role of Sufis, Pirs and cultural mediators in propagating Islam imbued Bengal Islam with esoteric, liberal and local cultural elements and secondly, this local influence along with the asraf/atraf ${ }^{94}$ dichotomy periodically subjected the people to the pressures of orthodoxy in the shape of various revivalist and purificatory movements. The role of cultural mediators during the early phase of spread of Islam prevailed upon the belief structure, rituals, and precepts of Bengali Muslims. These local factors, particularly since the mid-nineteenth century, came under attack from revivalist movements such as Faraizi, Tariq-iMuhammadiyal, Ahl-i-Hadith, ${ }^{95}$ and the ideological historiography of the mid-twentieth

92

93

94

95

Ahmed, R., supra note 2; Wright, D., Islam and Bangladesh Polity, South Asia, vol. 10 no. 2 (1987), p. 15.

Roy, A., The Islamic Syncretistic Tradition in Bengal, Princeton 1983.

The most influential essay to claim the arab and ashraf origin of Bengali Muslims was Rubee, F., The Origin of Mussulman of Bengal, Calcutta 1895; reprinted in the Journal of East Pakistan History Association, vol. 1 (1968), pp. 1-63.

Khan, M.A., History of Faraidi Movement in Bengal, 1818-1906, Karachi 1965; Khan, M.A., Social and Political Implications of the Islamic Reform Movements in Bengal in the Nineteenth Century, in: Ahmed, R. (ed.), Bangladesh: Society, Religion and Politics, Chittagong 1985, pp. 81-94. But Nahar, $S$., The Agrarian Uprising of Titu Mir, 1831: The Economics of Revivalist Movement, The Journal of Bangladesh Studies, vol. 1 (1976), p. 105, has suggested that Titu Mir's movement was more an economic protest/revolt rather than religious revivalism; see also Kaviraj, N., Wahabi and Farazi Rebels of Bengal, New Delhi 1982, for agrarian content of these movements from a Marxist standpoint. 
century $^{96}$ accentuated the divide between the indigenous and perceived "pure" Islam. Invariably, these currents have compounded the issue of national loyalty and identity. ${ }^{97}$

While the fact of diverging loyalties has been amply analyzed, the search for a dominant trend, particularly in the well established instrumentalist / primordialist paradigm remains somewhat illusive. In broad terms:

"The primordialist argues that every person carries with him through life 'attachtments' derived from place of birth, kinship relationships, religion, language, and special practices that are 'natural' for him, 'spiritual' in character, and that provide a basis for an easy 'affinity' with other peoples from the same background ... while the instrumentalist refers to a perspective that emphasizes the uses to which cultural symbols are put by elites seeking instrumental advantage for themselves or the groups they claim to represent." ${ }^{98}$

In the subcontinental context the debate between primordialists and instrumentalists has revolved around the question whether the movement for Muslim Pakistan was rooted in the 'primordial' attachments of the Muslims of India an, therefore, inevitably led to a demand for a separate state once political mobilization was under way, or the creation of Pakistan was the clear manif estation of the instrumentalist notion of ethnicity so far as "Muslim separation was not pre-ordained, but resulted from the conscious manipulation of selected symbols of Muslim identity by Muslim elite groups in economic and political competition with each other and other elite groups among Hindus". 99

This theoretical framework has not been applied in recent writings on the political role of Islam in Bangladesh. ${ }^{100}$ However, recent analysis of the role of Islam in the political

96

Wright, D., Pakistani Identity and Historiography of Muslim Bengal, in: Park, L.R. (ed.), Pattern of Change in Modem Bengal, Michigan 1979, pp. 113-126, has summed the effort of ideological history in the following words: "The historiography of the Muslims in Bengal is therefore Pan Islamic in orientation. Periodization and the choice of crucial events depends not on the changing situation in Bengal, but on the history of Islamic world." (p. 115) A good portrait of Arabian affiliation of Bengal Muslim is in Hussain, S.S., Pakistan: An Anthology, Dacca 1964. For a critical overview of such ideological history see Ghaznavi, M., Recent Muslim Historiography in South Asia: The Problem of Perspective, Indian Economic and Social History Review, vol. 11 (1974), p. 183.

Wright, D., Origins of Bangladesh and Indian Ocean Relations (1971-75), New Delhi 1988, ch. I \& II for the identity issue; and the concluding remark in Ahmed, $R$., supra note 2.

Brass, P.R., Ethnicity and Nationalism: Theory and Comparison, New Delhi 1991, p. 72.

Ibid., at p. 76. For the debate between two principal proponents of the diverging views in Robinson, F., Nation Formation: The Brass Thesis and Muslim Separatism, and Brass, P.R., A Reply to Francis Robinson, Journal of Commonwealth and Comparative Politics, vol. xv no. 3 (1977), pp. 215-234. See also Robinson, F., Separatism among India Muslims: The Politics of the United Province's Muslims, 1860-1923, New Delhi 1975; Brass, P.R., Language, Religion and Political Identity: A 100 General Framework, in: Taylor, D. / Yapp, M. (eds.), Political Identity in South Asia, London 1979.

The only exception that I am aware of is Wright, D., supra note 17. 
context of Bangladesh clearly indicates an almost unconditional acceptance of the instrumentalist version of imposition of Islamic identity on Bengali nationalism. ${ }^{101}$ But attempts to explain the position of Islam in primordialist term is not unheard of. ${ }^{102}$

There is, however, a clear recognition that political manipulation rather than unmitigated primordial identity accounts for occasional resurgence of Islamic political currents in Bangladesh polity. ${ }^{103}$ The fact that occasional reemergence of Islamic trends in the polity is most of ten explained in terms instrumentalist manipulation is a clear manifestation of the limited role of political Islam.

The present multi-party democratic political situation is bound to impinge on the instrumentalist network, and coupled.with the recently emerging articulation in favour of secular politics in the popular print media, which was absent in the 1971-75 and almost impossible in 1975-1990, signify a major shift away from political role of religion. Recent judicial pronouncements in such a milieu partake in the secularization of not only the legal system but the polity also.

${ }^{101}$ For example, Rafiuddin Ahmed wrote: "Orchestrated by the military rulers who have been in power since 1975, and influenced by recent developments in the Muslim world, ... Islamic symbols have regained political influence in the country in recent years", in: Ahmed, $R$. (ed.), Religion, Nationalism and Politics in Bangladesh, New Delhi 1990, p. 27; and Syed Anwar Hussain states: "The present study posits the view that certain intemal variable and external inputs have been providing the 'specific catalyst' (for resurgence of Islam) for Bangladesh", in: Ahmed, $R$. (ed.), above, p. 141. In similar vein Veena Kukreja writes: "Ziaur Rahman had manipulated symbols intelligently to recruit the support of the Islamists. He emphasized Islamic symbols and slogan in public meetings and appearance ...", in: Kukreja, V., Civil-Military Relations in South Asia, New Delhi 1991, p. 163.

102

For example: "The present upsurge of fundamentalism is nothing but a revival of that primordial identity", in: Gulati, C.J., Bangladesh: Liberation to Fundamentalism, New Delhi 1988, p. 233.

103

The only electoral success of religion based politics came about in 1946 when Bengal Provincial Muslim League won 114 of the 119 Muslim seats. However, even this 1946 election can hardly be taken as an indication of total support for an Islamic polity as it was achieved largely as a result of support of Chief Minister Suhrawardy, who after the election, in collaboration with the "... socialist General Secretary Abul Hashim announced their plan for 'Sovereign Independent United Bengal' on 24 April 1947 outside both India and Pakistan", in: Sen, R., Political Elite in Bangladesh, Dhaka 1986, p. 63. See also Jalal, A., The Sole Spokesman: Jinnah, the Muslim League, and the Demand for Pakistan, Cambridge 1985, pp. 264-266, 280-281, for an account of negotiations by Suhrawardy for an independent Bengal. 
three levels of inner-administrative review: the ombudsperson's office (xinfangchu), the Administrative Supervision and the Administrative Reconsideration organisations.

The Administration Litigation Law, enacted in 1989, expressly states that abstract administrative actions cannot be accepted by the courts for review. But Chinese legal scholars are intensively debating the way the courts will still be considering administrative regulations and to what extent they are bound by them.

The prospect that judicial review will soon be used in China as a checking device is rather low. Separation of powers is not part of the Chinese governmental structure and one-party rule makes an independent judiciary, a precondition for judicial review as well as publicly available law, a myth. Several suggestions are put forward how to implement changes in the review system which could lead to judicial review in the long run.

\section{Recent Case Law on Custody and Second Marriage in Bangladesh: A Trend Towards Secularisation of the Legal System?}

\section{By Shahdeen Malik}

Bangladesh, in its recent history, has gone through several periods of changing influence of Islamic principles and norms on the one hand and secularism on the other hand with respect to its constitution, legal system and society. The article discusses the nature of these influences with a comparative view to other Islamic and Christian countries. It argues that despite the constitutional Islamic character of the state, according to a respective constitutional amendment in 1988, recent case law in matters of Muslim family law is applying liberal-egalitarian paradigm instead of Islamic norms. This trend towards a secularization of the legal system seems to point to an emerging societal consensus concerning the role of religion in state and polity. 